trade that will inhibit its growth as little as possible, while satisfying all reasonable political desires. 6 :

\section{Bibliography of Seismology}

THrs valuable biblifgraphy is being continued by Dr. Ernest An F a lgson; Pub. Dominion Observ., Ottawa, 13, N. 16, 17 and 18, comprise items 5788-6048. Nhe bibliography is concerned with publicatins in pure and applied seismology and oth subjects having a direct bearing on seismologida problems. It is pleasing to see notes of Russian work, much of which was done during the War. One such is by E. E. Petrenko, "A Net of Co-ordinates for Determining the Epicentre of an Earthquake" (Akademiia Nauk, U.S.S.R., Trudy Seismolog. Inst., No. 106, 12-16, Moscow, 1941). This is in Russian, but it has been translated by W. Ayvazoglow and V. Skitsky for Geophysical Abstracts. Greek work is largely centred on the collected papers of Prof. N. A. Critikos, published by his colleagues on the occasion of the thirty-fifth anniversary of his scientific work (Item 5901). An especially important piece of American work is listed as Item 5956, by D. S. Carder, "Seismic Investigations in the Boulder Dam Area 1940-41, and the Influence of Reservoir Loading on Local Earthquake Activity" (Bull Seis. Soc. Amer., 35, No. 4, 175-192, Oct. 1945). This work has been particularly successful in locating epicentres of small shocks and associating them with fault planes. It may easily have far-reaching results on reservoir engineering. Considerable useful work has been done in New Zealand; for example, Item 5980, by W. M. Jones, refers to three papers, including "Determination of Epicentres in the South Pacific from Differences in the Arrival Times of SeS" (N:Z. J. Sci. and Tech., 26 , No. $6 \mathrm{~B}, 366-369)$. This paper shows that there is less ambiguity in epicentral determination using $S c S$ pulses than when using $P$ pulses in certain cases owing to less variation caused by the depth of focus. British work is mentioned, including Item 5862, Prof. H. -H. Plaskett's tribute to the seismological work of Miss E. F. Bellamy; Item 5880, Sir George Simpson's tribute to the work of the late Dr. F. J. W. Whipple; and Item 5930, by Dr. R. Stoneley, "Earthquakes" (Observ., 66, No. 824). There is also a list of references published in Nature.

\section{University of London: Appointments}

THE following appointments have been made: Dr. C. A. Hart, to the University chair of surveying and photogammetry tenable at University College as from gctober 1; in 1927 he became assistant lecturer/n the Department of Municipal Engineering and $H$ giene at University College, and during 194246 bo was officer in charge of research, Directorate of Mifitary Survey, War Office: Dr. C. V. Harrison, to the University readership in morbid anatomy tenable at the British Postgraduate Medical School as from October 1, 1946 ; Dr. Harrison was formerly lecturer in pathology in the University of Liverpool, and since 1944 has been chief pathologist to the Ministry of Supply and chief consultant in pathology to the Admiralty.

The following doctorates have been conferred: D.Sc. : Mr. W. E. Duncanson, recognized teacher of University College; D.Sc.(Eng.) : Dr. Harold Heywood, Imperial College of Science and Technology; D.Sc.(Econ.) : Mr. K. H. L. Key, Institute of Education.

\section{Re-opening of the British Museum (Natural History) \\ Those poptions of the British Museum (Natural} History) that have been restored have been re-opened to the pyrlic. The hours of opening are 10 a.m.-6 p.m. on wo kdays, and 2.30 p.m.-6 p.m. on Sundays. The Museum suffered considerably from bomb-blast and fires resulting from air raids during the War. Zittle or no irreplaceable material was lost, as all the most valuable specimens had been evacuated to places of safety. But the Botanical and Shell Galleries were destroyed (the latter fortunately being empty at the time), and in many of the galleries exhibits were damaged, notably those of birds and mammals in the Western Wing. The Museum has been re-opened as soon as the minimum of essential repairs could be completed, but as yet the public can be admitted to only a few of the galleries on the ground floor, namely, the Central and North Halls, the Fish Gallery, the Insect Gallery, the Reptile Gallery and the Whale Hall. Selections of specimens from the more seriously damaged parts of the exhibition are on view temporarily in these galleries. As the work of repair and reconstruction proceeds, more galleries will become available for exhibition purposes and will be reopened.

\section{Announcements}

Prof. C. Lander, who has just retired from the chair of mechanical engineering at the City and Guilds College, University of London (see Nature, Augast 10, p. 191), has been appointed dean of the Military College of Science.

DR. JACOB 1 AKKER, of the Netherlands State Coalmines, has joined the National Coal Board in Great Britain as adviser to the chief mining engineer. $\mathrm{He}$ is widely recognized throughout the coal-fields of Europe as a leading expert on 'horizon mining', that is, driving main roadways straight out from the pitbottom and working the coal wherever it is struck.

Dr. Frank BeLL, principal of Lancaster Technical College since 1941, has been appointed professor of chemiory at the Belfast College of Technology in suceossion to Dr. Henry Wren. Dr. Bell has held previous appointments at the Wellcome Chemical Research Laboratories, Blackburn Technical College and Battersea Polytechnic.

A David Anderson-Berry Silver-Gilt Medal, together with a sye of money amounting to about $£ 100$, will be ayyrded during 1947 by the Royal Society of Edjoburgh to the person who, in the opinion of the Gruncil, has recently produced the best work on the therapeutical effect of X-rays on human diseases. Applications for this prize are invited. They may be based on both published and unpublished work and should be accompanied by copies of the relevant papers. Applications must be in the hands of the General Secretary, Royal Society of Edinburgh, 22 George Street, Edinburgh 2, not later than January 31,1947 . It should be noted that an extension of the period allowed for the receipt of papers has been made.

Erratum The "wonderful one-hoss shay" rereferred to in Nature of October 19, p. 537, was wrongly attributed to Longfellow; the phrase comes from Oliver Wendell Holmes' “The Deacon's Masterpiece". 